\title{
Anti-inflammatory and analgesic activities of Vatavidhvamsana rasa, An Ayurvedic herbo-mineral formulation
}

\author{
Research Article
}

\section{Mahesh S1*, Swapnil Y Chaudhari², Mukesh Nariya ${ }^{3}$, Patgiri B $\mathbf{J}^{4}$}

\author{
1. Research Officer, Central Ayurveda Research Institute, CCRAS, Patiala, Punjab. \\ 2. Assistant Professor, 4. Professor and Head of the Department, \\ Department of Rasasastra and Bhaishajya Kalpana,
}

3. Head of the Department, Department of Pharmacology, Institute of Teaching and Research in Ayurveda, Gujarat Ayurveda University, Jamnagar.

\begin{abstract}
Background: Inflammation is a complex process mainly comprises of three phases namely acute, sub-acute and chronic. In acute inflammatory conditions fluid and granulocytic cells accumulate at the site of injury because of the changes in small blood vessels. This response often activates systemic response such as leucocytosis, protein catabolism, fever and synthesis of C-reactive protein, an acute-phase protein In Ayurvedic texts, several herbomineral preparations to fight against inflammation have been found; among them, Vatavidhvamsana Rasa (VVR) is one, which is said to be remarkable in inflammation condition. Aim and Objectives: To assess the anti-inflammatory and analgesic effects of VVR in pharmacologically validated models. Materials and methods: Wistar strain albino rats weighing $200 \pm 20$ of either sex were used in the study. VVR was administered at a dose of $22.5 \mathrm{mg} / \mathrm{kg}$ for the rat. Results: Vatavidhvamsana Rasa (VVR) showed a significant decrease in the carrageenan-induced paw oedema after 1 -hour interval in comparison to the control group $(\mathrm{P}<0.05)$ and at 3 hours and 5 hours intervals it showed a nonsignificant decrease in carrageenan-induced paw oedema in albino rats. In the analgesic activity, VVR treated group showed a significant increase in radiant heat response at $30 \mathrm{~min}$. interval $(\mathrm{P}<0.05)$ and non-significant increase at 60 mins in comparison to initial and control group. Conclusion: The results concluded that Vatavidhvamsana Rasa has anti-inflammatory and analgesic activity. Accordingly, it can be used in the management of pain and inflammatory conditions.
\end{abstract}

Key Words: Analgesic, Anti-inflammatory, Pain, NSAID, Herbominerals, Vatavidhvamsana Rasa.

\section{Introduction}

Inflammation, although first characterized by Cornelius Celsus, a physician in first Century Rome, it was Rudolf Virchow, a German physician in the nineteenth century who suggested a link between inflammation and cancer, cardiovascular diseases, diabetes, pulmonary diseases, neurological diseases and other chronic diseases. Scientific researches in the last decades has established these remarks and recognized the molecular basis for many chronic diseases with associated inflammatory responses. (1) Conventional management of inflammation and pain includes varied groups of drugs; of them, Non-steroidal antiinflammatory drugs (NSAIDs) are the most commonly used anti-inflammatory and analgesic drugs. NSAIDs have the capacity to block the synthesis of prostaglandin and hinder the synthesis of lipoxygenase

* Corresponding Author:

\section{Mahesh S}

Research Officer,

Central Ayurveda Research Institute,

Central Council for Research in Ayurvedic Sciences,

Patiala, Punjab. India

Email Id: drmaheshmtg@gmail.com and superoxide radical. It also upset neutrophil aggregation and adhesion, cytokine production and cartilage metabolism etc. (2) Antiinflammatory, analgesic and antipyretic actions are due to a common mechanism, that is, inhibition of COX-2 and COX-1, however, simultaneous inhibition of COX-1 result in unwanted side effects. (3)

In the recent context, contemporary medicines have found cures for many health problems including some infectious diseases that cause sickness and premature death on a large scale. These contemporary drugs offer potent treatment for several common ailments, but they also bring a high risk of adverse reactions, which in some cases become distressing. Accordingly, shortfall of the treatment, it becomes mandatory that one should search for medicaments that can defeat all these peculiarities. In this order, a search has been made through the field of Ayurveda for medicines that can execute the requirements. Several preparations to fight inflammation have been found in classical Ayurvedic manuals. Vatavidhvamsana Rasa is a well-known Ayurvedic herbomineral formulation widely used for various neuromuscular diseases. When analysing the ingredients of VVR, most of the drugs were having Sophahara (anti-inflammatory) and Sulahara (analgesic) properties as per Ayurveda. (4) So 
the formulation may have analgesic and antiinflammatory properties. The study is planned to revalidate the anti-inflammatory and analgesic activities of the VVR in suitable experimental animal models.

\section{Materials and methods \\ Test formulation}

Vatavidhvamsana Rasa (VVR), is mentioned in Yogaratnakara, written in the $18^{\text {th }}$ century AD which is also quoted in Ayurvedic Formulary of India (AFI). (5) Raw materials were procured from the Pharmacy of Institute and were identified and authenticated by the Pharmacognosy department and faculty of RSBK department of the institute as per the standards of Ayurvedic Pharmacopeia of India. Preparation of Kajjali (a combination of $\mathrm{Hg}$ and $\mathrm{S}$ ) is by grinding one part each of processed mercury and processed sulphur using mortar and pestle, till it attains a lusterless black fine powder form. (6) Then one part each of Maricha powder (Piper longum Linn.), Naga Bhasma (processed lead), Vanga Bhasma (processed tin), Tamra Bhasma (processed copper), Abhraka Bhasma (processed mica), Loha Bhasma (processed iron), Tankana (processed borax), and two parts each of Pippali powder (Piper longum Linn.), Shundi powder (Zingiber officinale Roscoe), was added one by one to the Kajjali and triturated well using a Khalvayantra. After that 4.5 parts of Shodita Vatsanabha Churna (Aconitum Chasmanthum Staff. Ex.Holmes) was added and triturated well to form a uniform fine mixture. This was triturated three times each of the ten media (Table 1). Then the final product was dried in shade and stored in an airtight glass container.

\section{Table 1: Ingredients of Vatavidhvamsana Rasa}

\begin{tabular}{|c|c|c|c|}
\hline No & Ingredients & Parts & Media for levigation \\
\hline 1 & $\begin{array}{l}\text { Shodita } \\
\text { Parada }\end{array}$ & 1 part & $\begin{array}{l}\text { Three times triturated in each } \\
\text { of the following drugs }\end{array}$ \\
\hline 2 & $\begin{array}{l}\text { Shodita } \\
\text { Gandaka }\end{array}$ & 1 part & $\begin{array}{l}\text { 1. Decoction of Trikatu } \\
\text { 2. Decoction of Triphala }\end{array}$ \\
\hline 3 & Vanga Bhasma & 1 part & 3. Decoction of Plumbago \\
\hline 4 & Naga Bhasma & 1 part & zeylanica Linn. \\
\hline 5 & Tamra Bhasma & 1 part & 4. Juice of Eclipta alba \\
\hline 6 & Loha Bhasma & 1 part & Hassk. \\
\hline 7 & $\begin{array}{l}\text { Abhraka } \\
\text { Bhasma }\end{array}$ & 1 part & $\begin{array}{l}\text { 5. Decoction of Sausserea } \\
\text { lappa C.B.Clarke }\end{array}$ \\
\hline 8 & $\begin{array}{l}\text { Shodita } \\
\text { Tankana }\end{array}$ & 1 part & $\begin{array}{l}\text { 6. Juice of Vitex negundo } \\
\text { Linn. }\end{array}$ \\
\hline 9 & Pippali & 2 part & 7. Latex of $A r k a$ \\
\hline 10 & Shunthi & 2 part & 8. Juice of Bhumiamalaki \\
\hline 11 & Maricha & 1 Part & 9. Decoction of Lepidium \\
\hline 12 & $\begin{array}{l}\text { Shodita } \\
\text { Vatsanabha }\end{array}$ & $4 \frac{1}{2}$ Parts & $\begin{array}{l}\text { sativum Linn } \\
\text { 10. Juice of Citrus lemon }\end{array}$ \\
\hline
\end{tabular}

\section{Animals}

Wistar strain albino rats of either sex weighing $200 \pm 20 \mathrm{~g}$ were obtained from the animal house attached to the pharmacology laboratory attached to the Institute. The animals were given potable water ad libitum and given 'Amrut' brand animal pellet feed (manufactured by Pranav Agro Industries). The animals were kept in optimum temperature and humidity and they were allowed for natural day-night cycles. The experiments were carried out in conformity with the guidelines of the Institutional Animal Ethics Committee after obtaining its permission (approval number IAEC/ 24/2018/21) and care was taken as per Committee for the Purpose of Control and Supervision of Experiments on Animals (CPCSEA) guidelines.

\section{Dose fixation}

The dose of the test formulation of rats was fixed by using table of Paget and Barnes. (7) Thus the adult human dose of test drug VVR (250 mg per day) was converted to rat dose on the basis of body surface area ratio as per the table $(22.5 \mathrm{mg} / \mathrm{kg}$ p.o $)$. The test drug was suspended in distilled water by making a uniform suspension with honey with suitable concentration depending upon the bodyweight of the animals and administered orally with the help of a gastric catheter connected to a syringe. The drug was administered to overnight-fasted animals.

\section{Experimental protocols}

\section{Anti-inflammatory activity Carrageenan-induced paw oedema in rats $(8)$}

The Wistar strain albino rats of either sex were weighed and randomly, divided into three groups of six each. The first group (control group) received potable water. The second group received the test drug, Vatavidhvamsana Rasa (VVR) and the third group was administered with standard anti-inflammatory drug phenylbutazone (model 520, IITC Life Science Inc.) at a dose of $100 \mathrm{mg} / \mathrm{kg}$. (9) The test drug was administered to the second group for five consecutive days, whereas the standard drug was given only once on the fifth day, one hour before the carrageenan injection. The left hind paw volumes up to the tibiotarsal articulation was recorded before the carrageenan injection by using a plethysmograph. $(10,11)$ After one hour of drug administration, oedema was produced by injecting 0.1 $\mathrm{ml}$ freshly prepared $1 \% \mathrm{w} / \mathrm{v}$ carrageenan in sterile saline solution to the sub-plantar aponeurosis of the left hind limb of the rat. The animals were given potable water in $2 \mathrm{ml} / 100 \mathrm{~g}$ body weight to ensure proper hydration. This in turn helps to reduce the variations in oedema produced. The intensity of oedema formation over paw was recorded after one, three and five hours of carrageenan injection. The results obtained after one, three and five hours were stated as the percentage increase in paw volume compared to the initial values of paw volume.

\section{Analgesic activity radiant heat-induced pain by hot plate method (12)}

A heat-conductive surface, such as metal, is heated to a temperature that will induce a nociceptive response in an animal subject normally $50-56^{\circ} \mathrm{C}$. The animal is then placed onto the surface and prevented from leaving the platform by blockades. The latency to pain-reflex behaviour is measured. This model executes the effect of test drug on the latency of paw licking or jump response, which represents pain threshold, was measured in rats employing the procedure of 
incremental hot plate. In this experiment, the paw licking or jump response was observed by the IITC incremental Hot plate. The IITC incremental Hot plate is designed to enable the operator a more precise reading of thresholds due to temperature than the standard constant temperature hot plates used for latencies. When the animal reacts to the heat the test is stopped and the plate will automatically be cooled to the user set standby temperature. The Wistar albino rats weighing between $200 \pm 20 \mathrm{~g}$ of both sex were randomly selected and distributed in three groups of six each.

The first group served as the control group received potable water. The second group received the test drug, Vatavidhvamsana Rasa (VVR, $22.5 \mathrm{mg} / \mathrm{kg}$ p.o.). The third group was administered the standard analgesic drug Pentazocine $(20 \mathrm{mg} / \mathrm{kg}$, p.o.). The effect of the test drug on the latency of paw licking or jump response, which represents pain threshold, was measured in rats employing the procedure of incremental hot plate. The animals were positioned on an incremental Hot plate kept at a temperature of $55 \pm 0.5^{\circ} \mathrm{C}$. A cut off period of $15 \mathrm{sec}$ was observed to avoid damage to the paw. (13) The initial reading was noted for each rat for paw licking or jump response. The test drugs were administered to respective groups and distilled water to the control group. The latency of onset of reaction time was again recorded at 30, 60, 120, 180 and $240 \mathrm{~min}$ after the administration of the drug. $(14,15)$

\section{Statistical Analysis}

The obtained results were presented as Mean \pm SEM. The data generated during the study were subjected to Student Paired and Unpaired ' $t$ ' test, as well as one way ANOVA, followed by Dunnett's multiple ' $t$ ' test as post-hoc test applicable. A value of $\mathrm{P}<0.05$ was considered to be significant.

\section{Results}

The result shows that Vatavidhvamsana Rasa showed a significant decrease in the carrageenaninduced paw oedema $(\mathrm{P}<0.01)$ after 1-hour interval in comparison to the control group $(\mathrm{P}<0.05)$ and at 3 hours and 5 hours intervals it showed a non-significant decrease in carrageenan-induced paw oedema in albino rats. Phenyl butazone treated group showed a highly significant decrease in carrageenan-induced paw oedema after 1 hour and 5 hours when compared to the control group (Table 2). The data related to the effect of test drugs on radiant heat-induced pain through the hot plate model at different intervals in rats are tabulated in Table 3. The normal control group showed a nonsignificant decrease in response to radiant heat at alltime intervals. VVR treated group showed a significant increase in radiant heat response at $30 \mathrm{~min}$. interval and non-significant increase at 60 minutes in comparison to initial and control group. Pentazocine treated group showed a highly significant increase in radiant heat response at all-time intervals compared to the control group as well as initial readings.

Table 2: Effect of test drugs on carrageenan-induced paw oedema in albino rats

\begin{tabular}{|c|c|c|c|}
\hline \multirow{2}{*}{ Groups } & \multicolumn{2}{|c|}{ \% Increase in paw oedema at different time interval } \\
\cline { 2 - 4 } & After 1h & After 3h & After 5h \\
\hline NC & $33.58 \pm 3.38$ & $44.12 \pm 8.79$ & $62.01 \pm 3.36$ \\
\hline VVR & $21.78 \pm 1.94 * @$ & $35.64 \pm 5.58$ & $47.95 \pm 9.81$ \\
\hline SC & $15.22 \pm 2.06^{* * * @ @ ~}$ & $32.58 \pm 2.77$ & $33.58 \pm 3.38^{* * * @}$ \\
\hline
\end{tabular}

NC- Normal control, SC-Standard control, VVR-Vatavidhvamsana Rasa,Data: Mean \pm SEM;

${ }^{*} \mathrm{P}<0.05,{ }^{* *} \mathrm{P}<0.01,{ }^{* * *} \mathrm{P}<0.001$ compared to normal control group (Unpaired ' $\mathrm{t}$ ' test); $@ \mathrm{P}<0.05$, @@ $\mathrm{P}<0.01$ compared to normal control group (Annova followed by Dunnett's multiple ' $t$ ' test)

Table 3: Effect of test drugs on radiant heat response in albino rats

\begin{tabular}{|c|c|c|c|c|c|c|}
\hline \multirow{2}{*}{$\begin{array}{l}\text { Oral treatment } \\
(\mathrm{mg} / \mathrm{Kg})\end{array}$} & \multicolumn{6}{|c|}{ Latent period } \\
\hline & Initial & 30 min. & 60 min. & 120 min. & 180 min. & 240 min. \\
\hline $\mathrm{NC}$ & $3.28 \pm 0.11$ & $3.17 \pm 0.11$ & $3.09 \pm 0.14$ & $2.92 \pm 0.19$ & $3.09 \pm 0.25$ & $3.01 \pm 0.43$ \\
\hline VVR & $2.90 \pm 0.17$ & $3.44 \pm 0.08^{*}$ & $3.13 \pm 0.42$ & $2.63 \pm 0.21$ & $2.59 \pm 0.19$ & $2.38 \pm 0.36$ \\
\hline $\mathrm{SC}$ & $3.02 \pm 0.12$ & 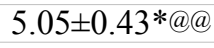 & 5.43土0.28***@@ & 6.24士0.63***@@ & 5.29土0.40***@@ & $4.90 \pm 0.36^{* * * @ a ~}$ \\
\hline
\end{tabular}

\section{Discussion}

Inflammation is a complex process mainly comprises of three phases namely acute, sub-acute and chronic. In acute inflammation, due to change in small blood vessels, fluid and granulocytic cells accumulate at the site of injury. This response often activates a systemic response such as leucocytosis, protein catabolism, fever and synthesis of C-reactive protein, an acute-phase protein. (16) In conditions where inflammation is inappropriate, acute inflammation can cause considerable morbidity hence drugs with antiinflammatory activity would be required to meet the contingencies in such situations. The test formulation was evaluated against carrageenan and formaldehyde induced acute paw oedema to assess its effect on acute inflammation and cotton pellet induced granuloma formation to assess its effect on chronic inflammation. Carrageenan induced rat paw oedema has been a popular inflammatory model to investigate the antiinflammatory potency of compounds or natural products. A high degree of reproducibility was exhibited by this experimental model. (17) According to Vinegar et al (1969), a carrageenan-induced paw oedema is a biphasic event. The first phase of reaction was generated within one hour and is attributed to the release of histamine, serotonin and kinins and partly due to the trauma produced by injection. The second phase 
of oedema is due to the release of prostaglandins $(\mathrm{PG})$, protease and lysosome. Most of the clinically effective anti-inflammatory drugs are effective in the second phase. Prostaglandins play a major role in the development of the second phase of the reaction, which is measured around $3 \mathrm{~h}$. The presence of PGE2 in the inflammatory exudates from the injected foot paw can be demonstrated at $3 \mathrm{~h}$ and thereafter. (18) The present study revealed that the test drug suppresses carrageenan-induced paw oedema in the initial phase which is statistically significant when compared to normal control while after 3 and 5 hours it shows a statistically non-significant decrease. Thus, the drug is very effective in the early stages of inflammation and might stop the release of histamine, serotonin and kinins and in the late phase also showed noticeable suppression in oedema in albino rats. "Pain is an unpleasant sensory and emotional experience associated with actual or potential tissue damage" this is a definition given by IASP (International Association for the Study of Pain). (19) Pain-relieving drugs act on peripheral or CNS to selectively reduce pain without altering consciousness. (20)

The animal model employed for screening analgesic activity in this study is the pain-state model using thermal stimuli which include the hot plate method. This method is useful in illustrating centrally mediated ant nociceptive responses which focus generally on changes above the spinal cord level. (21) Hot plate strategy includes higher brain capacities and is respected as a supraspinally organized reaction. (22) In this show, tactile nerves sensitize the nociceptors and the association of endogenous substances such as prostaglandins are minimized. (23) VVR treated group showed a significant increase in radiant heat response at 30 minutes interval but no significant changes at other intervals in comparison to the initial as well as the control group. Pentazocine treated group showed significant analgesic activity in radiant heat response at all-time intervals compared to the control group as well as initial readings. The hot plate model, which is thermal-induced nociception, indicates narcotic involvement, which is sensitive to opioid receptors. Pain is centrally modulated via several complex processes including opiate, dopaminergic descending noradrenergic and serotonergic systems. (24) The mild to moderate increase in pain threshold produced by test drug in early phase at 30 mins interval in this model, suggests the involvement of central pain pathways. The analgesic effect produced by VVR and standard drug in the early phase possibly will be through central mechanisms (by receptor systems) or through peripheral mechanisms like inhibiting the release of prostaglandins, leukotrienes, and other endogenous substances. Glycosides, Flavonoids and tannins present in the plant extract may be responsible for the analgesic activity because it is well established that a wide range of bioactivities is dependable to these phytochemicals. (25)

As mentioned earlier, Vatavidhvamsana Rasa contains metals and minerals like Mercury, Sulphur, Lead, Tin, Copper, Iron, Mica, and Aconitum
Chasmanthum Staff. Ex.Holmes. It is indicated for Sula (pain), Vatakapha diseases, Grahani (Irritable bowel syndrome), Sootika rogas (Post-partum pain syndromes), Apasmara (epilepsy). The main ingredient, Vatsanabha is having Sulahara (analgesic) and Yogavahi (catalyst) property. (26) Vatsanabha is also indicated in different conditions like Gridhrasi (sciatica), Katisoola (low backache), Sirasula (Headache) etc. Certain drugs like Chitraka, Kushta, Chandrsoora, Nirgundi and Trikatu are known to be having Sulahara (analgesic) property. (27-31) Altogether while we analyze the combination it is a very good analgesic drug. The indications described point out the fact that this combination of Vatavidhvamsana Rasa is effective in musculoskeletal, post-traumatic/surgical and visceral pain. These properties may be given in revealing anti-inflammatory and analgesic activities of the VVR.

\section{Conclusion}

The study validated the claim for the use of Vatavidhvamsana rasa in inflammation and pain Accordingly, it can be used in the management of pain and inflammatory conditions.

\section{Financial support and sponsorship}

Financial support for this experimental study was given by Institute of Teaching and Research in Ayurveda (I.T.R.A), Gujarat Ayurved University, Jamnagar 361008.

Conflicts of interest: There are no conflicts of interest.

\section{References}

1. Bharat B. Aggarwal, Sahdeo Prasad, Simone Reuter, Ramaswamy Kannappan, Vivek R. Yadev, Byoungduck Park, Ji Hye Kim et al. Identification of Novel Anti-inflammatory Agents from Ayurvedic Medicine for Prevention of Chronic Diseases: "Reverse Pharmacology" and "Bedside to Bench" A p proach. Curr Drug Targets 2011;12(11):1595-1653

2. Bennet.P.N, M.J. Brown. Clinical pharmacology (9th ed.), Elsevier, Churchill Livingstone ; 2005. p. $282-283$

3. Hardman J.G., L.E. Limbird, A.G. Gilman. Goodman Gillman's the pharmacological basis of therapeutics (10 $10^{\text {th }}$ ed.), Mc Graw Hill 2001. p. 694

4. Indradev Tripathi, Yogaratnakara of Vaidya Ixmipati sastri, $1^{\text {st }}$ edition., Chaukamba Krishnadas Academy Varanasi 1998.p.436-437

5. Anonymous. The Ayurveda Formulary of India. $2^{\text {nd }}$ edition, New Delhi: Government of India, Ministry of Health \& Family Welfare, Department of Indian System of Medicine \& Homoeopathy, Part 12008. p.722

6. Kasinatha Misra(ed.),Rasatarangini of sadanantha sarma, 8th edi, Mothilal banarasidas, 2014. p.124

7. Paget GE, Barnes JM. Evaluation of drug activities. In: Lawrence DR, Bacharach AL, editors. 
Pharmacometrics. Vol. 1.New York: Academic press;1964. p.161

8. Winter E.A. Risley George W. Nuss. CarrageeninInduced Edema in Hind Paw of the Rat as an Assay for Antiinflammatory Drugs. Proc Soc Exp Biol Med. 1962;111:544-7.

9. Chowdhury S, Nishteswar K, Nariya MK. Analgesic and anti-inflammatory effects of aqueous extract of leaves of Pentatropis capensisLinn. f. (Bullock). Ancient Sci Life 2014;34:64-7

10. Winter CA, Risely EA, Nuss GW. Carrageenan induced oedema in hind paw of the rat as assay for anti-infl ammatory drugs. Proc Soc Exp Bio Med 1962;111:544-7.

11. Bhatt KR, Mehta RK, Srivastava PN. A simple method for recording anti-inflammatory effect on rat paw oedema. Indian $\mathrm{J}$ Physiol Pharmacol 1977;21:399-400.

12. Eddy.N.B and D. Leimbach, "Synthetic analgesics. I I. Dithienylbutenyl-and dithienylbutylamines," Journal of Pharmacology and Experimental Therapeutics 1953; 107(3):385393

13. Franzotti E, Santos C, Rodrigues H, Mourao R, Andrade M, Antoniolli A. Anti-inflammatory, analgesic activity and acute toxicity of Sida cordifolia L. (Malva-branca). Journal of Ethnopharmacology, 2000; 72:273-277

14. Kulkarni SK. Handbook of Experimental Pharmacology. 3rd ed. New Delhi: Vallabh Prakashan; 1999. p.232

15. Toma W, Graciosa JS, Hiruma-Lima CA, Andrade FD, Vilegas W, Souza Brita AR. Evaluation of the analgesic and antiedematogenic activities of Quassia amara bark extract. J. Ethnopharmacol. 2003,85: 19-23

16. Harsh Mohan, Text book of Pathology, sixth edition, Published by Jitendar P Vij Jaypee Brothers Medical Publishers (P) Ltd. 2010.p.623

17. Anti-inflammatory activity of Dalbergia lanceolaria bark ethanol extract in mice and rats, Kale M. et al, journal od Ethnopharmacology 2007.112(2):300-4

18. An experimental evaluation of anti-inflammatory activity of dashanga agada w.s.r. to keeta visha (insect bite), Dr. Bhavani VP, Dr. Sudheendra Honwad and Dr. Shrinidhi Ballal, The Pharma Innovation Journal 2018; 7(8): 223-226

19. Merskey.H. Pain terms: a list with definition and notes on usage. Recommended by the IASP Subcommittee on Taxonomy, Pain 1979; 6: 249-252
20. Tripathi.K.D., Essentials of Medical Pharmacology, Jaypee Brothers Medical Publishers, New Delhi, India, 5th edition, 2004.p.123

21. Wigdor S. and Wilcox G. L. "Central and systemic morphine induced antinociception in mice: contribution of descending serotonergic and noradrenergic pathways, Journal of Pharmacology and Experimental Therapeutics 1987;242(1):90-95. 25.

22. Chapman C. R., Casey K. L., Dubner R., Foley K. M., Gracely R. H., and Reading A. E.. "Pain measurement: an overview," Pain 1985; 22(1):1-31.

23. Bachlav RS, Gulecha VS, Upasani CD. Analgesic and Anti-inflammatory Activity of Argyreia Speciosa roots. Indian J Pharmacol. 2009;41(4):158-161.

24. Headley PM, Shaughnessy CT. Evidence for opiate and dopamine interaction in striatum. Br. J. Pharmacol.1985;86:700-5

25. Bibi Y, Nisa S, Waheed A, Zia M, Sarwar S, Ahmed $S$, et al. Evaluation of Vibumum foetens for anticancer and antibacterial potential and phytochemical analysis. Afr J Biotechnol 2010; 9(34): 5611-5615.

26. Kasinatha Misra(ed.),Rasatarangini of sadanantha sarma, 8th edi, Mothilal banarasidas, 2014.p.646

27. Agnivesha, Charak Samhita, Chaukhambha Orientalia, section 6 Chikitsasthanam, Varanasi 1998. p. 12

28. Juluri Krishna DuttaTejaswi,Rajan R. Govinda , Sara P. Biological evaluation of saussurea lapparoot extract for analgesic and a nti-inflammatoryactivity, Asian Journal of Pharmaceutical Research and Development, 2018;6 (4): -35-38.

29. Srikantha Murthy K.R.BhavaPrakasha by Bhavamisra, with English translation, , Vol.1, Krishna Das Academy, Varanasi, 2001.p.16-24.

30. Yasmeen A. Maniyar, Dasari Sriraj, Peripheral and central analgesic activity evaluation of ethanolic extract of Vitex Negundo flowers in experimental animals, 2017: 6(11):145-8.

31. Harwansh, R.K., Mukherjee, K., Bhadra, S., Kar,A., Bahadur, S., Mitra, A., Mukherjee, P.K. Cytochrome P450 inhibitory potential and RPHPLC standardization of Trikatu-A Rasayana from Indian Ayurveda.J. Ethno-pharmacol., 2014; 153:674-681. 